\title{
Historical materials from the post-Cistercian abbey in Kamieniec Ząbkowicki (southwestern Poland)_application of mineralogical methods for identification of source of raw materials
}

\author{
Wojciech Bartz $^{1}$ - Jakub Kierczak ${ }^{1}$ - Maria Gąsior ${ }^{2}$ Piotr Wanat ${ }^{3}$
}

Received: 10 February 2015 / Accepted: 30 July 2015 /Published online: 14 August 2015

(C) The Author(s) 2015. This article is published with open access at Springerlink.com

\begin{abstract}
In this paper, we use a set of methods applied for geosciences to reveal the provenance of raw materials and historical aspects of technology of lime production from the post-Cistercian church (southwestern Poland). Two types of building stones (mica schists and sandstones) and two groups of mortars, related with two different construction phases (Gothic and Baroque), were used for construction of the church façade. Principal difference between binding materials involves the presence of Mg-rich phase within Baroque mortars as a result of carbonation of a dolomitic lime whereas Gothic mortars are devoid of hydromagnesite. Mineral composition of the fillers of both mortars is similar, suggesting the same origin represented by local eluvium. Binders of studied mortars are composed of calcite and/or hydromagnesite and rich in lime lumps suggesting incomplete calcination. Studied mortars are weathered which is manifested by presence of gypsum. However, there is no evidence of commonly occurring Mg-rich secondary phases within Baroque mortar probably due to higher solubility of these salts comparing to gypsum. Mineralogical study combined with archeological and geological information enables us to indicate potential sources for the studied building materials. Metamorphic rocks, prevailing within the façade, come from abandoned quarries
\end{abstract}

Wojciech Bartz

wojciech.bartz@ing.uni.wroc.pl

1 Institute of Geological Sciences, University of Wrocław, pl. M. Borna 9, 50-205 Wrocław, Poland

2 Laboratory for Technological and Conservation Research, Faculty of Architecture, Wrocław University of Technology, ul. Rozbrat 7, 50-334 Wrocław, Poland

3 Restoart Pracownia Konserwatorska Piotr Wanat, ul. Chmielna 1, 51-212 Wrocław, Poland located in the closest vicinity of the church, whereas sandstones were acquired from the deposits located at a distance of tens of kilometers from the Kamieniec Zabkowicki. Raw materials used for lime burning were gathered from Przeworno (Gothic mortars) and Złoty Stok area (Baroque mortars) located approximately $25-30$ and $12 \mathrm{~km}$ from studied church.

Keywords Historic mortar · Dolomitic lime · Provenance · Raw material $\cdot$ Petrography $\cdot$ Rubble masonry

\section{Introduction}

Over the past few decades, the archaeometric studies, focused on historical construction materials (mortars and plasters), have profited from application of methods used in geosciences. Through the study of chemical, physical, and mineralogical properties of these materials, scientists are able to obtain valuable information on production technology and provenance of raw materials used for construction.

Numerous studies dealing with mineralogical and physicochemical properties of construction materials are intended to (i) investigate the evolution in mortar technology and (ii) determine the provenance of raw materials (Elsen et al. 2011; Origlia et al. 2011; Agostino et al. 2013; Michalska et al. 2013). Furthermore, the detailed mineralogical and physicochemical investigations of historical mortars play a key role in the future restoration work (Montoya et al. 2004; Bartz et al. 2012). Several studies reveal, for example, that important differences may exist in the properties of lime mortars, even in the same area (Franzini et al. 1999; Crisci et al. 2004).

In spite of the fact that most of the historic mortars are composed of lime consisting of calcium hydroxide, Mg-rich mortars were also identified in some medieval or baroque 
mortars (Bruni et al. 1998; Alvarez et al. 2000; Bartz et al. 2013; Kozlowski et al. 2014). This indicates that these materials can be very diverse. Elsen et al. (2011) pointed out that variability in mortar composition reflects differences in source materials. Furthermore, they stress the need of site-specific studies focused on time-related changes in mortar technology resulting from changes in mortar components. Finally, it can differentiate building phases of investigated monument (Biscontin et al. 2002; Carò et al. 2008).

In this context, the present work constitutes a detailed mineralogical study of the historical plasters and building stones from the Cistercian church (ABVM\&JE), located in the Lower Silesia, SW Poland. The knowledge on the materials and technology used for erection and reconstruction of the Cistercian church is very limited. Preliminary results (Bartz et al. 2013) showed that there exists variability in the composition of mortars, corresponding to specific construction phases. However, there is no comprehensive study of the whole structure. Regarding the natural stone, Lisowska (2013) suggested the lithology for rocks found in the walls of the church. Their provenance was outlined too. However, this study was not supported by in-depth petrological study. This vestigial data stays in disharmony with extensive knowledge, with reference to complete and throughout history of the church (Wyrwa et al. 1999). Thus, the main aim of our research is twofold. First to fully characterize materials employed in the building's structure and on the basis of their expected differentiation to document various construction periods. To answer this question, we combine mineralogical analyses of building materials, detailed information about geology of the studied area, and some previous archaeological information and, secondly, to attempt determine the provenance of raw materials (building stones as well as mortars) used for construction of the studied object.

\section{Historical information}

The church of the Assumption of the Blessed Virgin Mary and St. James the Elder is located in the Kamieniec Ząbkowickia small town in the southwestern Poland (Fig. 1). The official records date back to the tenth century, when the Czech prince Břetislav II erected a defensive stronghold there (Wyrwa et al. 1999). In the beginning of the thirteenth century, Augustinians began erection of a new church, by raising part of the outer walls. In 1251, the monastery was taken over by the Cistercians, what was ultimately approved by the Pope Innocent IV. The monks continued the construction of the Gothic temple and adjacent monastic buildings to the middle of the fourteenth century. This is the first in the Polish lands and the only Cistercian three-nave hall temple, built on a Latin cross plan. The outer walls of the church are composed of the quarry-faced stone, whereas the inner nave walls, vaults, and

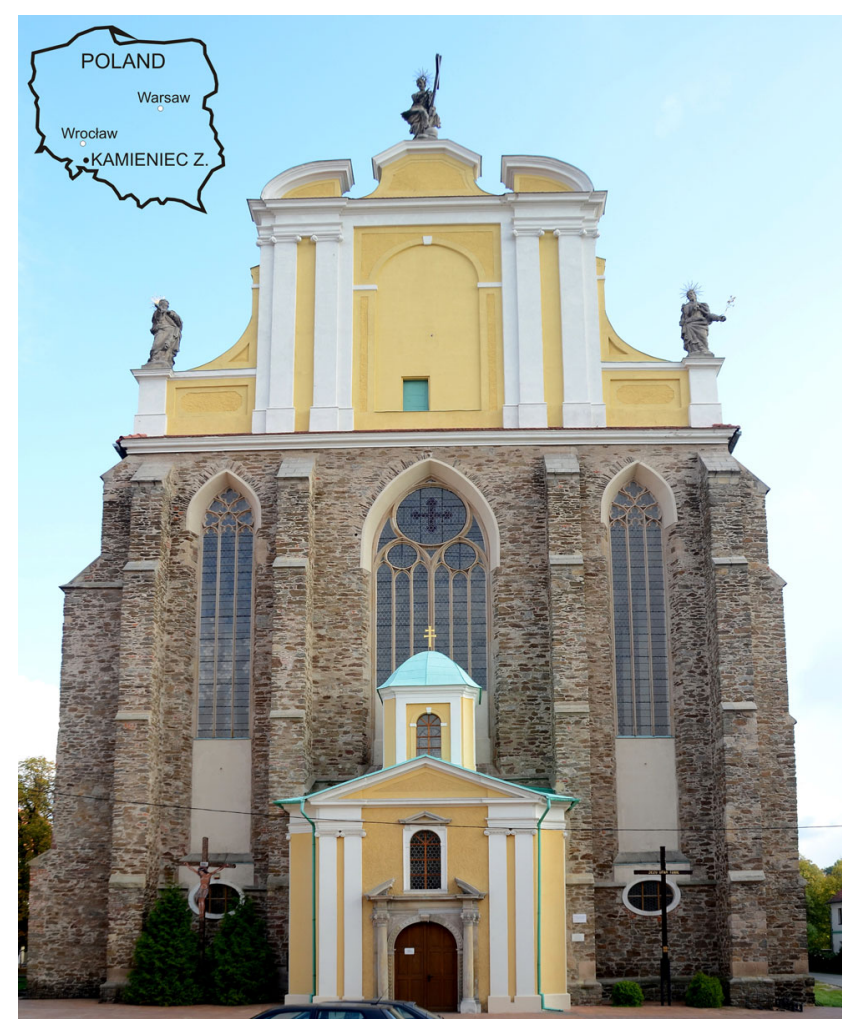

Fig. 1 Western façade of the church of the Assumption of the Blessed Virgin Mary and St. James the Elder in Kamieniec Zabkowicki and its location on the map of Poland

the gable of the façade are built of Gothic and Baroque brick, respectively. Major changes of the church took place in the early eighteenth century, during the reign of Abbot Augustine Neudeck. He ordered a wide-ranging reconstruction of the church, including plastering of the walls, rebuilding of presbytery and chapels, erection of vestibule from the Western side, etc. Such significant investments considerably strained funds of the Abbey. Finally, the Cistercian convent was secularized in 1810. In 1817, there was a fire, which partly affected the church but completely destroyed the monastery (Fig. 2). The latter one was demolished, soon after that. In the years 1902-1914, the restoration work was carried out, when the Baroque plasters were removed, exposing the walls composed of quarry-faced stones. Nowadays, the abbey church serves as a parish church, whereas a branch of the State Archives in Wrocław occupies preserved buildings of adjacent former cloister.

\section{Geological settings}

Figure 3 shows the geology of the studied area. The rocks cropping out there belong to the geological unit called Kamieniec Ząbkowicki Metamorphic Complex (Józefiak 2000; Mazur and Józefiak 1999) or Kamieniec Ząbkowicki Metamorphic Belt (Gurgurewicz and Bartz 2011). It is mostly 
Fig. 2 Schematic plan of the church of the Assumption of the Blessed Virgin Mary and St. James the Elder in Kamieniec Ząbkowicki (modified after Wyrwa et al. 1999)

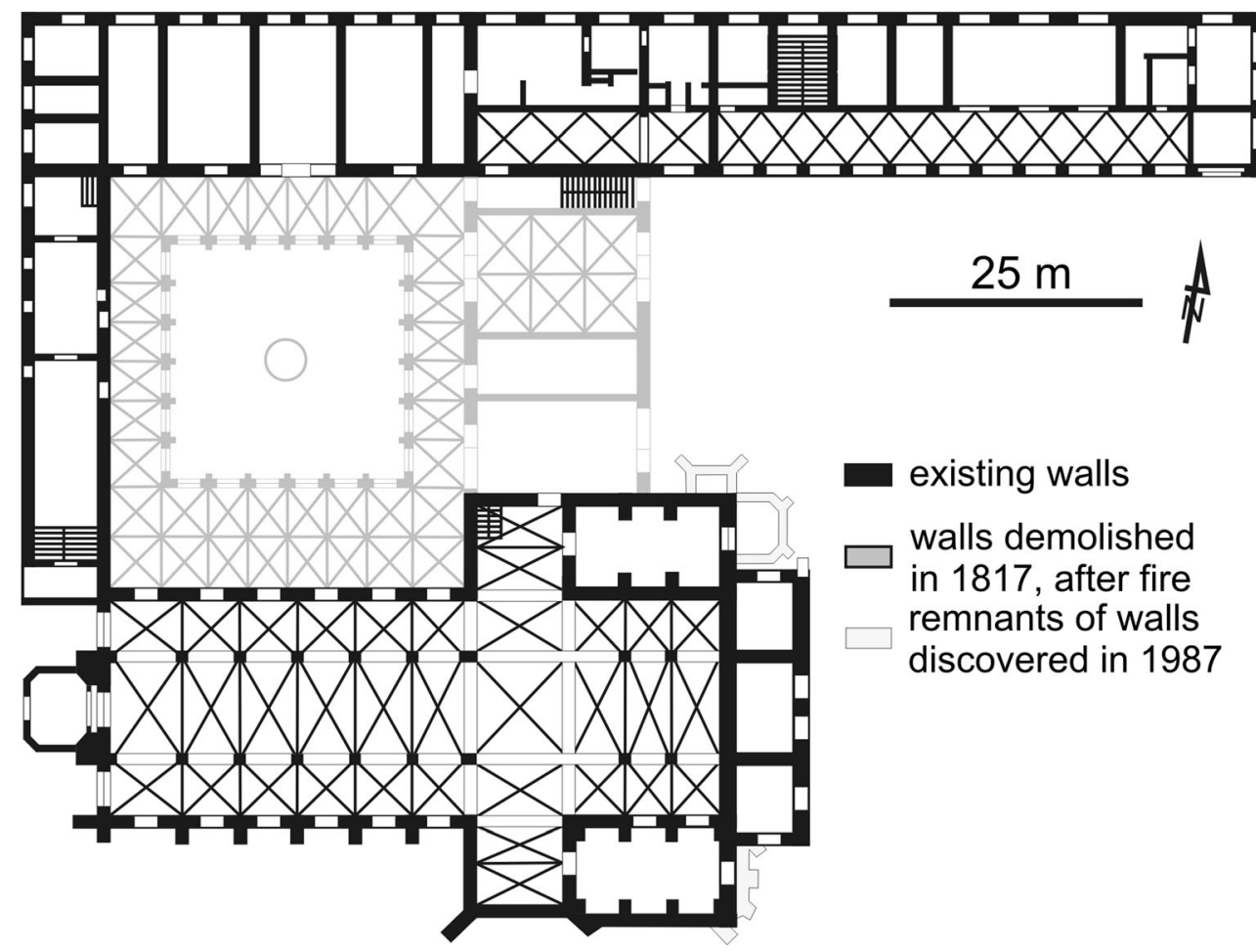

composed of crystalline rocks, metamorphosed during the Caledonian and the Variscian orogenesis, with protolith age estimated as Ediacaran-Cambrian on the basis of some problematical Acritarcha (Gunia 1979). Furthermore, the area of
Fig. 3 a Geological sketch map of the Kamieniec Zabkowicki area (modified after Mazur and Józefiak 1999). b Location of studied church in Kamieniec Ząbkowicki town. Arrows correspond to the transport direction of Radków Sandstone

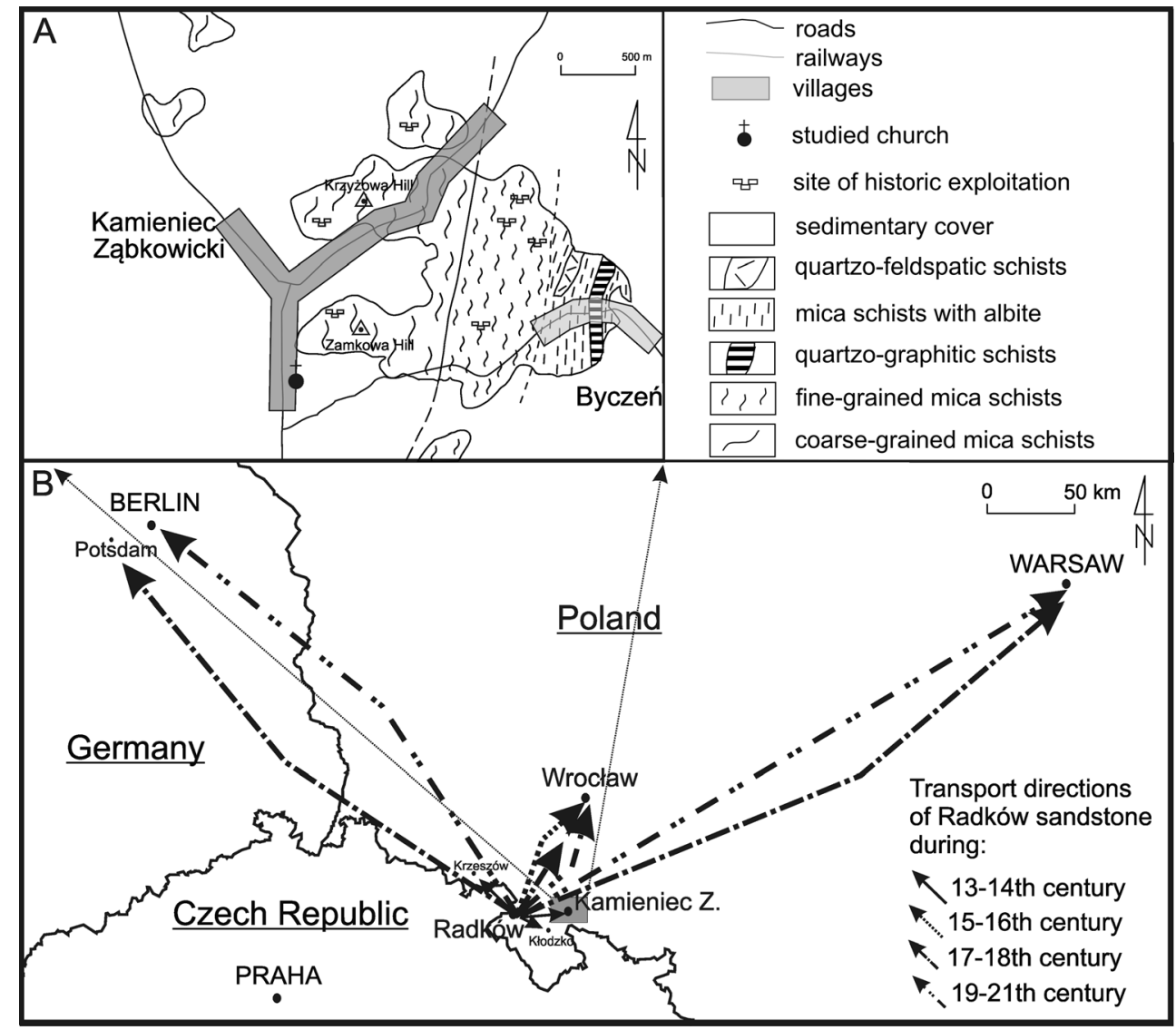


the described geological unit is partially covered by younger Cenozoic sediments (Fig. 3a). This results in outcropping of the crystalline basement in the form of numerous hills, well visible in the terrain morphology. The crystalline rocks are predominantly represented by mica schists, constituting a bedrock in the closest vicinity of the ABVM\&JE church. They are intercalated with amphibolites, quartzo-feldspathic schists, and quartzo-graphitic schists or enclose small bodies of eclogites and marbles (Mazur and Józefiak 1999; Andrzejewski 2000; Gurgurewicz and Bartz 2011). The mica schists occur as several varieties: a fine-grained one, a coarsegrained one, both containing garnet, staurolite, and andalusite porphyroblasts, and, locally, an albite-bearing one (Fig. 3a, Mazur and Józefiak 1999; Józefiak 2000).

The mica schists have never undergone an exploitation on a large scale. However, during archaeological work, Lisowska (2013) has found a number of small quarries, located eastward the Kamieniec Zabkowicki and the Lopienica villages. Furthermore, she proved that the mica schists have been used since the early Middle Ages, for the production of grinding stones, hones, and a stone for the construction of sacral buildings.

\section{Materials and methods}

The stones and mortars represent original material collected from the Gothic façade and its Baroque gable (Figs. 1 and 2). The latter include jointing mortars as well as plastering mortars. The second-mentioned are preserved only locally, as small patches, which makes them very valuable artifact. We analyzed representative samples of the following: (i) stucco mortars from the gable and (ii) plastering and joining mortars as well as natural building stones from the façades (Table 1).

In order to fully characterized sampled mortars, we followed the procedure given by Middendorf et al. (2000). As a first step, according to Arıoglu and Acun (2006), samples were studied by means of stereomicroscope. It was followed by polarizing optical microscopy (POM) of thin sections
(Blaeuer and Kueng 2007; Elsen 2006) by use of Zeiss petrographic microscope. Subsequently, in order to examine the microstructure of mortars and their chemistry, scanning electron microcopy (SEM) was applied, using Vega LSU Tescan equipped with energy-dispersive X-ray spectroscopy (EDS) system of INCA Penta-FETx3 Oxford Instruments. The observations were performed on fresh broken surface, coated with carbon, at accelerating voltage of $20 \mathrm{kV}$. The next step of our approach was X-ray powder diffraction (XRD) and simultaneous thermal analysis (differential scanning calorimetry-thermogravimetry (DSC-TG)). Prior to analysis, samples were dried, crushed, and sieved. Subsequently, the fraction smaller than $63 \mu \mathrm{m}$, mostly representing binder (Middendorf et al. 2000; Sandrolini and Franzoni 2010), was analyzed. DSC-TG curves were recorded with PerkinElmer STA 6000 system. The temperature range was $40-995{ }^{\circ} \mathrm{C}$ and a heating rate of $10^{\circ} \mathrm{C} / \mathrm{min}$. XRD analysis was performed on a Siemens D5005 powder diffractometer, working with $\mathrm{Co} \mathrm{K} \alpha$ radiation (with current $25 \mathrm{kV}, 25 \mathrm{~mA}$ ). The spectra were recorded in the $2 \theta$ range $4-75^{\circ}$, with step size $0.02^{\circ}, 1 \mathrm{~s} / \mathrm{step}$. Natural building stones taken from the façade and reference rock samples (Table 1) were examined by the same methods as mortars (stereomicroscopy and POM).

\section{Results and discussion}

\section{Characteristics and provenance of the building stones}

Two main types of natural building stones were identified within the façade of the ABVM\&JE church. The prevailing type is represented by mica schist (quarry-faced stone) whereas sandstones (dimension stone) occur in subordinate amounts.

The natural building stone classified as a mica schist comprises two textural varieties, both having similar mineral composition, a clearly visible schistosity defined by oriented crystals of micas and a lepidogranoblastic texture, but differing in size of the individual components. First subtype has a fine-

Table 1 Details of the studied samples from the church of the Assumption of the Blessed Virgin Mary and St. James the Elder in Kamieniec Ząbkowicki and reference samples

\begin{tabular}{lllll}
\hline Sample group & Type of material & Assignable age & Sampling location & Samples quantity \\
\hline KZ1 & Stucco mortars & Baroque & Western façade, gable & 2 \\
KZ2 & Plastering mortars & Gothic & Western façade, below the gable & 1 \\
KZ-NS & Natural stones & Gothic & Western, northern, and southern façade & 7 \\
KZ3 & Joining mortars & Gothic & Western façade below the gable and northern façade & 5 \\
RF-LL & Mica schists-reference material & - & Zamkowa and Krzyżowa Hills & 18 \\
RF-P & Building sandstones-reference material & - & Historic and recent quarries in Lower Silesia & 17 \\
& & & (North Sudetic Basin and Intra-Sudetic Basin) & \\
\hline
\end{tabular}


grained microstructure (the size of individual constituents does not exceed $1 \mathrm{~mm}$; Fig. 4a) and occurs more frequently within the façade. Second subtype is coarse grained and composed of crystals having size often reaching up to $2 \mathrm{~mm}$ (Fig. 4b), and the individual crystals (e.g., garnet) are up to $7 \mathrm{~mm}$ in diameter. Both varieties of mica schists are composed of muscovite, biotite, and quartz as major minerals with subordinate feldspar and chlorite whereas garnet, andalusite, and opaques are accessory components. Muscovite and biotite form subhedral crystals of size up to 0.5 and $0.4 \mathrm{~mm}$, respectively, in fine-grained subtype and exceeding $2 \mathrm{~mm}$ in samples of coarse-grained schists. Those two minerals occur in studied rocks in varying proportions within mica layers defining the foliation of this rock: from $1 / 1$ to $1 / 2$ in fine-grained and from $1 / 6$ to $1 / 8$ in coarse-grained schists. Quartz forms lenticular aggregates composed of anhedral crystals of size reaching up to $1 \mathrm{~mm}$. Single crystals of muscovite and feldspar elongated parallel to foliation are present between the quartz grains.
Garnet occurs as isometric, subhedral porphyroblasts within quartz aggregates or rarely within mica layers. It reaches the size of approximately $1 \mathrm{~mm}$ in fine-grained variety whereas in coarse-grained schists, it has a diameter of $7 \mathrm{~mm}$. Garnet crystals are partly decomposed, strongly fractured, and overgrown with biotite, muscovite, chlorite, and quartz. Chlorite and opaques are present only within mica layers, where the former replaces biotite crystals whereas the latter forms subhedral to anhedral crystals or aggregates elongated parallel to foliation. Andalusite occurs as subhedral crystals of size up to $1 \mathrm{~mm}$. It generally forms aggregates composed of several grains of andalusite intergrown with biotite and muscovite.

Three types of mica schists crop out in the closest vicinity of the ABVM\&JE church (Fig. 3a, Mazur and Józefiak 1999; Józefiak 2000). These occurring directly in the area where the studied object is located correspond to coarse-grained mica schists described by Józefiak (2000); Fig. 4b). They consist of quartz, muscovite, biotite, plagioclase, chlorite, garnet,
Fig. 4 Microphotographs of studied samples (left column) and reference rocks (right column) viewed in cross-polarized light. a Fine-grained mica schist. b Coarse-grained mica schist. c Sandstone
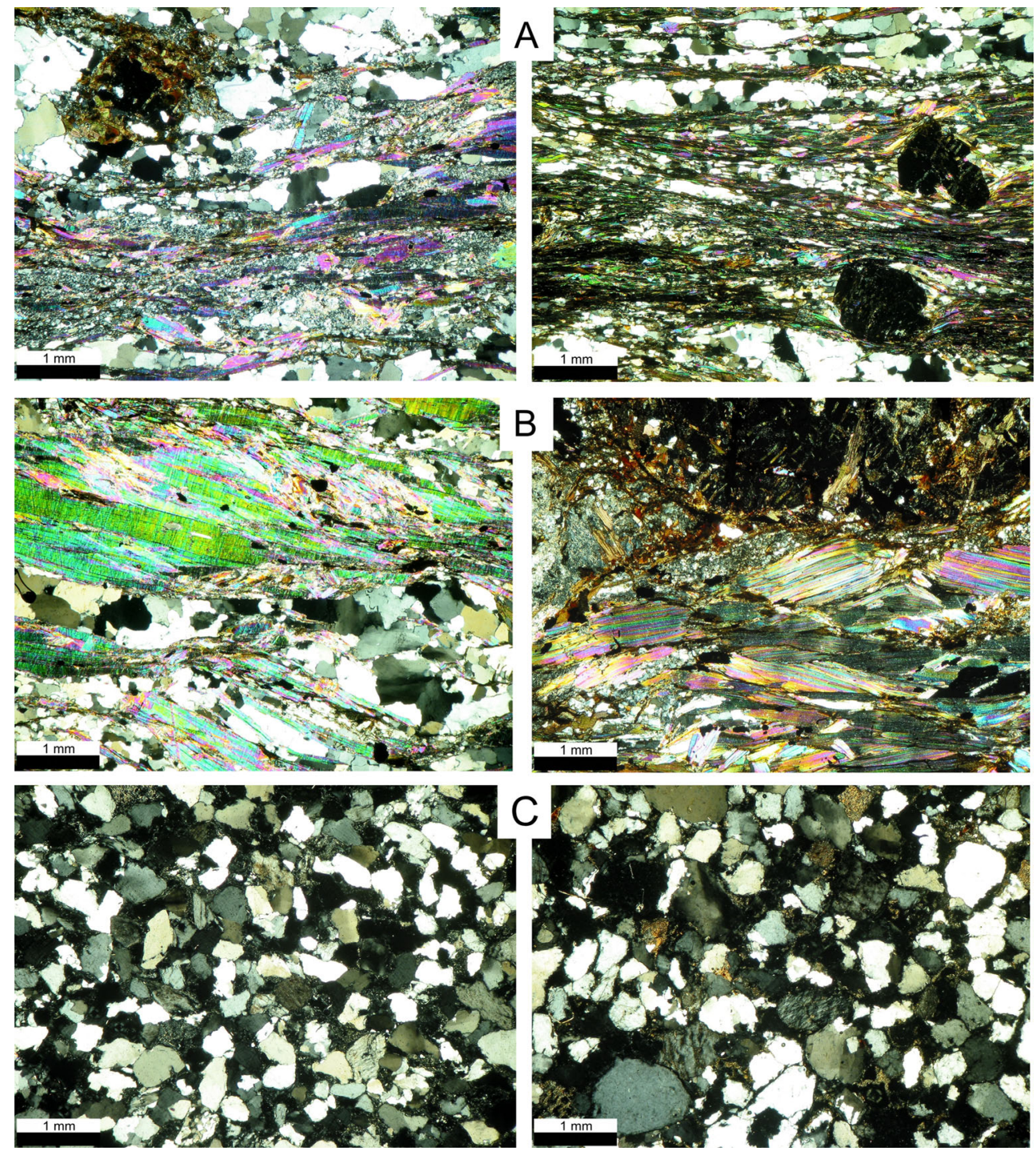
andalusite, silimanite, kyanite, rutile, ilmenite tourmaline, and apatite. The characteristic feature of these rocks is relatively large size of muscovite, andalusite, and garnet crystals, which reach a size of 4-10 mm (Józefiak 2000). Second type of mica schist distinguished by Józefiak (2000) occurs a few hundred meters east of the analyzed object (Fig. 3a). It is composed of the same set of minerals as previously described type; howev$\mathrm{er}$, it has fine-grained microstructure, and the majority of minerals is smaller than $2 \mathrm{~mm}$ (Józefiak 2000; Fig. 4a). Third type of rock occurring in the vicinity of the studied church corresponds to fine-grained mica schist with porphyroblasts of albite (Józefiak 2000). This rock consists of quartz, muscovite, biotite, plagioclase, minor chlorite, and garnet, whereas turmaline and opaques are accessory. The characteristic feature of this type of mica schist is an occurrence of porphyroblastic crystals of albite (up to $1.5 \mathrm{~mm}$, Józefiak 2000).

Based on petrographic description of natural building stone sampled from the façade of the studied church, we assume that walls of the church were built of coarse-grained and finegrained mica schist. Our hypothesis is confirmed by similar microstructure and mineralogy (e.g., presence of andalusite, absence of albite porphyroblasts) of studied building stone to those classified as fine- and coarse-grained mica schists (Józefiak 2000). Furthermore, archaeological excavations of the area situated close to Kamieniec Zabkowicki have confirmed the occurrence of several quarries of mica schists operating in the early Middle Ages (Lisowska 2013, Fig. 3a). Some of these quarries probably constitute the remnants of historical exploitation, which took place at the time of construction of the Augustinian monastery in Kamieniec Ząbkowicki (thirteenth century) and during its subsequent reconstruction (Lisowska 2013).

Second type of natural building stone used for construction of the façade of the ABVM\&JE church is represented by a yellow-gray sandstone. It occurs less frequently than the above-described mica schists; however, it is still an important element of the façade. The studied sandstone is mostly composed of quartz with minor amounts of feldspars (approximately up to $10 \mathrm{vol} \%$ ) and accessory lithic fragments (mainly cherts; Fig. 4c). According to sedimentary rocks classification (Pettijohn et al. 1987), the name of quartz arenite to subarcose is established for the studied sandstone. The shape of framework grains is generally subangular, and long, concavoconvex contacts between grains are most common. The rock is highly cemented with silica-clayous and locally ferruginized cement and has very low porosity. Petrographic characteristics of studied arenite (mineral composition of framework grains and cement, particle size distribution, and grain morphology) indicate that it corresponds to the Cretaceous joint sandstones from the North Sudetic Basin or Intra-Sudetic Basin. Three levels of joint sandstones of age from Cenomanian to Coniacian occur within these two geological units (Labus 2011). Generally, rocks from these localities do not contain or contain only accessory feldspars. Comparable amounts of feldspars to those observed in the façade of the church are noted only for Turonian joint sandstones from second level of both geological units (Labus 2011). We can therefore limit our consideration about the origin of the building sandstones to the following deposits: Radków, Długopole, Wolany (Intra-Sudetic Basin), and Jerzmanice (North Sudetic Basin). Furthermore, grain size distribution of studied quartz arenite is similar to this observed in sandstones from deposits Radków, Wambierzyce, and Długopole (Intra-Sudetic Basin; Ehling 1999). Archeological investigations of Lisowska (2013), who stated that several decorative elements of the church façade were made of sandstones exploited near Kłodzko (Intra-Sudetic Basin), help again to determine the source of the raw building material. Furthermore, several studies (Labus 2011; Labus and Hetmaniok 2004; Ehling 1999) also pointed out that sandstones from the Radków area, previously called Silesian sandstones, were used by eminent architects throughout Europe, particularly in the second half of the nineteenth and early twentieth century. The oldest sacral objects where Silesian sandstones from Radków were used for construction are represented by the post-Cistercian Monastery located in Krzeszów (Fig. 3b) dating to 1242 (Ehling 1999). Another example indicating that sandstones from Radków deposits were exploited presumably already in fourteenth century is located in Kłodzko and refers to the parish church of the Assumption of the Blessed Virgin Mary, where these rocks were used as the building stones (Labus 2011). It is also noteworthy that numerous architectural pearls, located sometimes many kilometers away from sandstone deposits in Radków, were built from that material. Most of these objects were constructed more recently, and the best known are represented by the Reichstag and the Brandenburg Gate in Berlin, Jasna Góra Monastery, Royal Castle in Warsaw, and Wawel Castle in Cracow (Fig. 3b; Labus 2011).

Petrographical investigations coupled with results of archeological studies clearly indicate that the majority of natural building stones used for construction of the ABVM\&JE church come from historical quarries of coarse-grained and fine-grained mica schist located east of Kamieniec Zabkowicki. Furthermore, part of the material (quartz arenite) used mainly for the decorative elements of the façade comes from sandstone deposits located in the Intra-Sudetic Basin at the vicinity of Radków town.

\section{Characteristics and diversity of mortars}

Two groups of mortars were identified on the basis of macroscopic as well as microscopic observations of studied samples. The materials correspond to previously distinguished constructing phases (Table 1) and differ in the presence/absence 
of magnesium-bearing phase in the binder. Baroque mortars, rich in $\mathrm{Mg}$ phase, belong to the first group, whereas Gothic mortars, with no Mg phase, belong to the second one. The first group includes samples consisting of single technical layer, with mean thickness of 2.0-3.0 mm, and, less frequently, of two technical layers: a priming coat with mean thickness of $10 \mathrm{~mm}$ covered with a finishing coat with mean thickness $5.0 \mathrm{~mm}$. The remnants of the two-layered mortar have been found in a profiled cornice of the gable. The single-layered mortar is preserved locally in the gable's plasters and in the pilaster's base and capital. Both single-layered and twolayered mortars are petrographically similar. The results of microscopic analysis indicate that quartz (mono as well as polycrystalline) and lithic grains (mica schists and crystalline rocks) are the main constituents of the filler. Feldspar grains are less common, whereas garnet, micas (biotite, muscovite), staurolite, and uncommon amphibole play an accessory role. The grains are subangular, angular to less common subrounded, with diameter generally not exceeding $1.0 \mathrm{~mm}$. Larger grains, reaching up to $1.5 \mathrm{~mm}$, are very sparse. Furthermore, the priming layer contains small amounts of crushed red ceramics as an admixture. The mineralogy of mortar's filler suggests that it was derived from the local eluvium of metamorphic bedrock, i.e., Cenozoic sedimentary rocks, enclosing the Zamkowa hill (Fig. 3a). The crushed ceramic admixture, used for centuries as artificial pozzolana (Elsen 2006), served as colorizing agent. The binder is a microcrystalline mass, composed of carbonates (micrite). It is strongly heterogeneous, rich in lime lumps (Fig. 5a, b). The presence of lime lumps is typical for all studied Baroque mortars. It indicates that mortars were poorly homogenized; the lime was dry slaked during a short time span and/or rich in underburnt carbonate rocks (Elsen 2006). SEM-EDS analysis revealed that microcrystalline binder is composed of two phases: a magnesium rich one - magnesite or hydromagnesite (Figs. 6c, d and 7b) - and a calcium rich one-calcite (Figs. 6a, b and 7a). Both of them occasionally contain small amounts of silicon, magnesium, and sulfur. Calcite occurs as fine-grained dense zones (micrite), whereas $\mathrm{Mg}$-rich phase forms distinctive, porous rosettes (Formia et al. 2014) of coarser-grained plates. Locally, the calcitic binder exhibits signs of recrystallization as a result of so-called autogenous healing (Fig. 7a). The secondary phase rich in sulfur is presumably gypsum. The variable sulfur contents document different stages of binder weathering. Secondary crystals of calcium sulfate (gypsum) form intergrowths in less-changed or even unweathered binder (Fig. 7c, d).

Combined XRD and DSC-TG analyses confirmed that calcite $\left(\mathrm{CaCO}_{3}\right)$ and hydromagnesite $\left(\mathrm{Mg}_{5}\left(\mathrm{CO}_{3}\right)_{4}(\mathrm{OH})_{2} \cdot 4 \mathrm{H}_{2} \mathrm{O}\right)$ are the main components of the binder. Decarbonation of calcite is evidenced by strong single weight loss, accompanied by endotherm, at the temperature above $600{ }^{\circ} \mathrm{C}$ (Fig. 8). Hydromagnesite, a typical constituent of dolomitic lime mortars, shows on the DSC curve peaks corresponding to the three-step endothermal decomposition. The release of molecules of water and crystallization starts at about $250^{\circ} \mathrm{C}$, continued at about $390^{\circ} \mathrm{C}$ (decomposition of the hydroxide) and final release of carbon dioxide at about $440{ }^{\circ} \mathrm{C}$ (Paama et al.
Fig. 5 Microphotographs of Baroque mortar $(\mathbf{a}, \mathbf{b})$ and Gothic mortar (c, d) viewed in planepolarized light (left column) and cross-polarized light (right column)
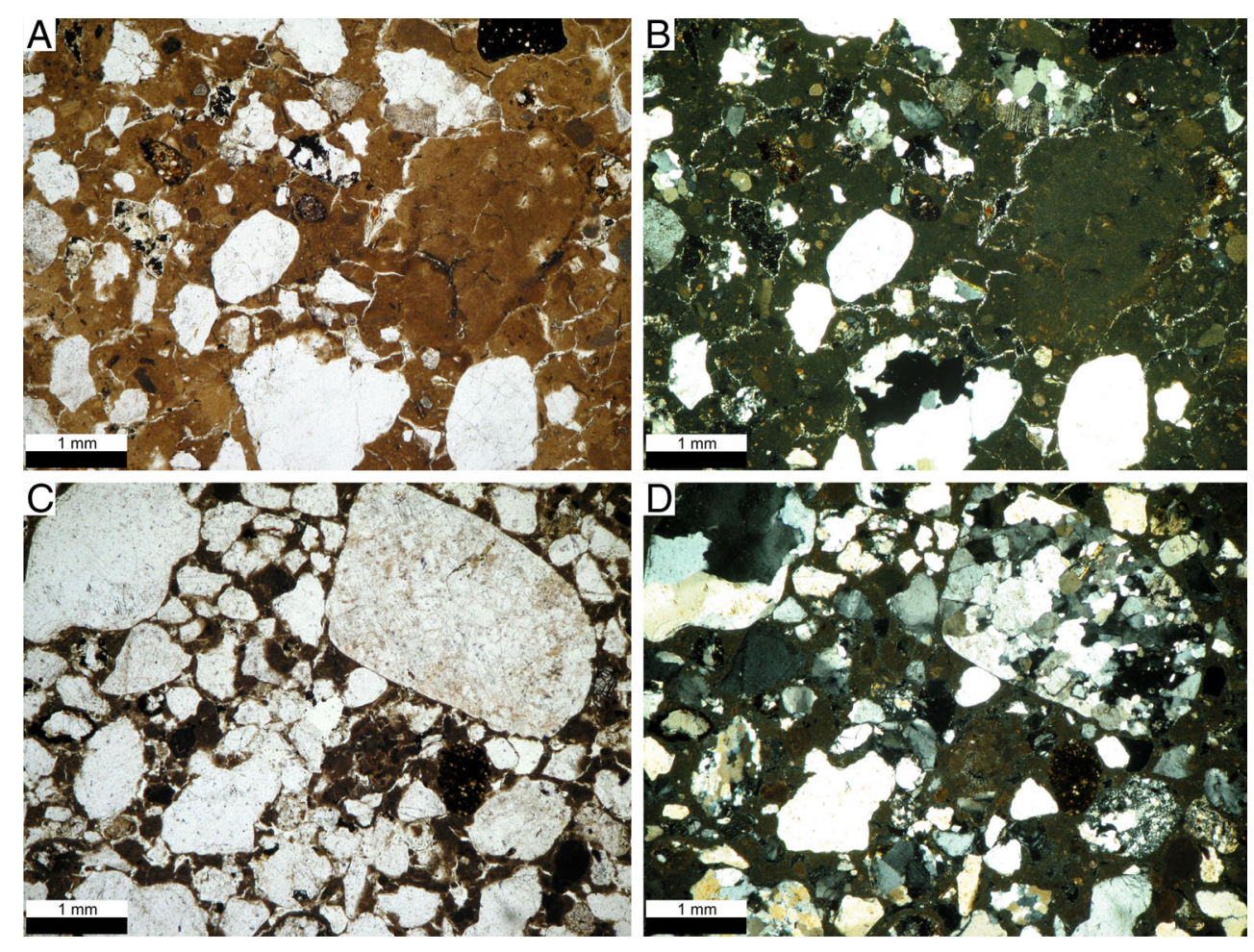

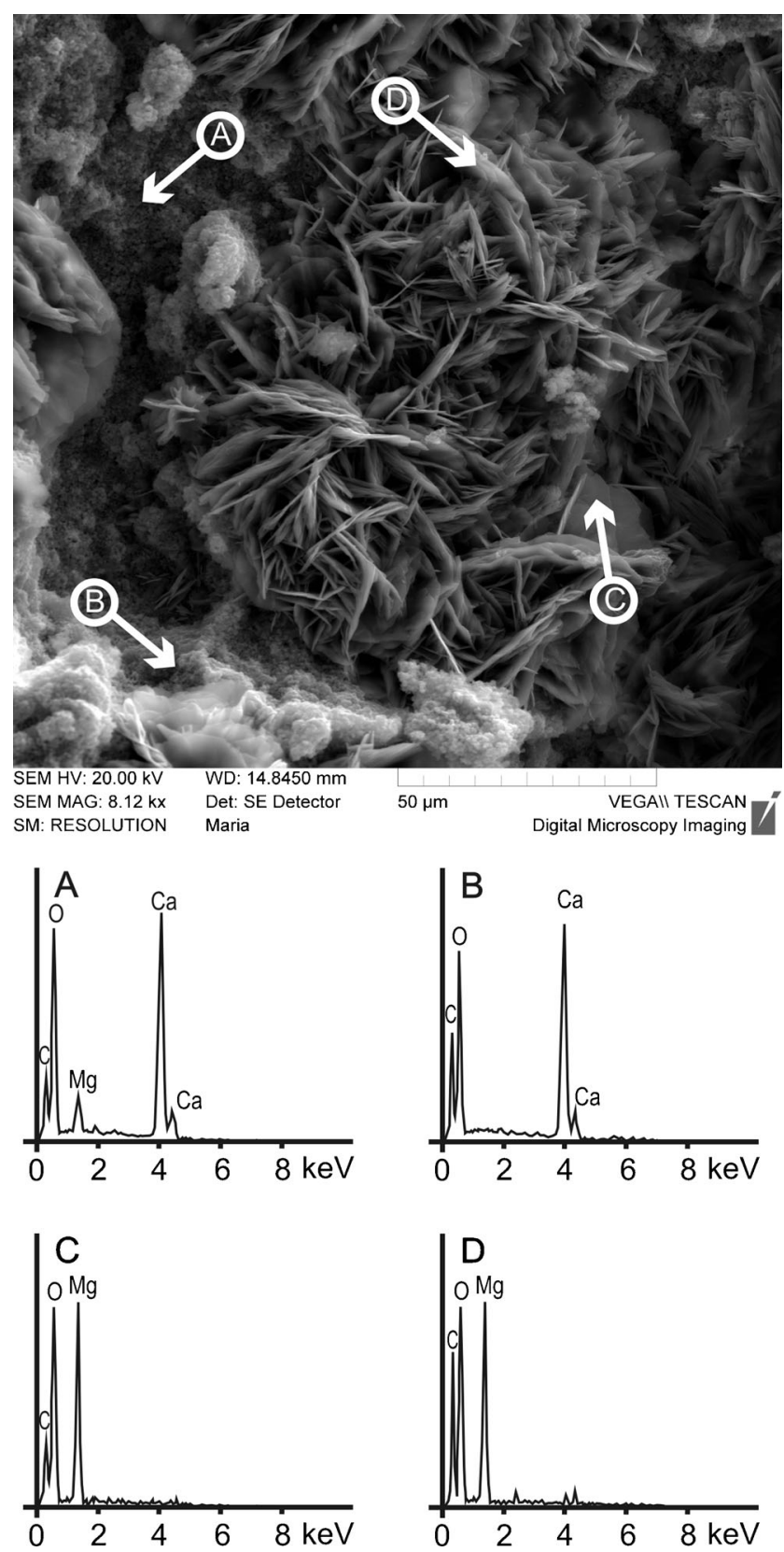

Fig. 6 Secondary electron images and EDS spectra of Baroque Mortar (priming layer)

1998; Alvarez et al. 2000; Ramachandran et al. 2002). Despite the fact that Montoya et al. (2003) questioned use of thermal studies to verify presence of hydromagnesite in ancient binding materials, presence of hydromagnesite and calcite was confirmed by XRD analyses (Fig. 9). The hydromagnesite resulted from the hydration and carbonation of $\mathrm{MgO}$ in the lime paste in a moist $\mathrm{CO}_{2}$-rich atmosphere (Dheilly et al. 1999; Formia et al. 2014). Siedel et al. (2010) observed that, through the reaction with $\mathrm{CO}_{2}$, hydromagnesite content changes in mortar's profile. In mature mortars, it coexists with brucite (magnesium hydroxide) in deeper zones, whereas it is replaced with thermodynamically stable magnesium
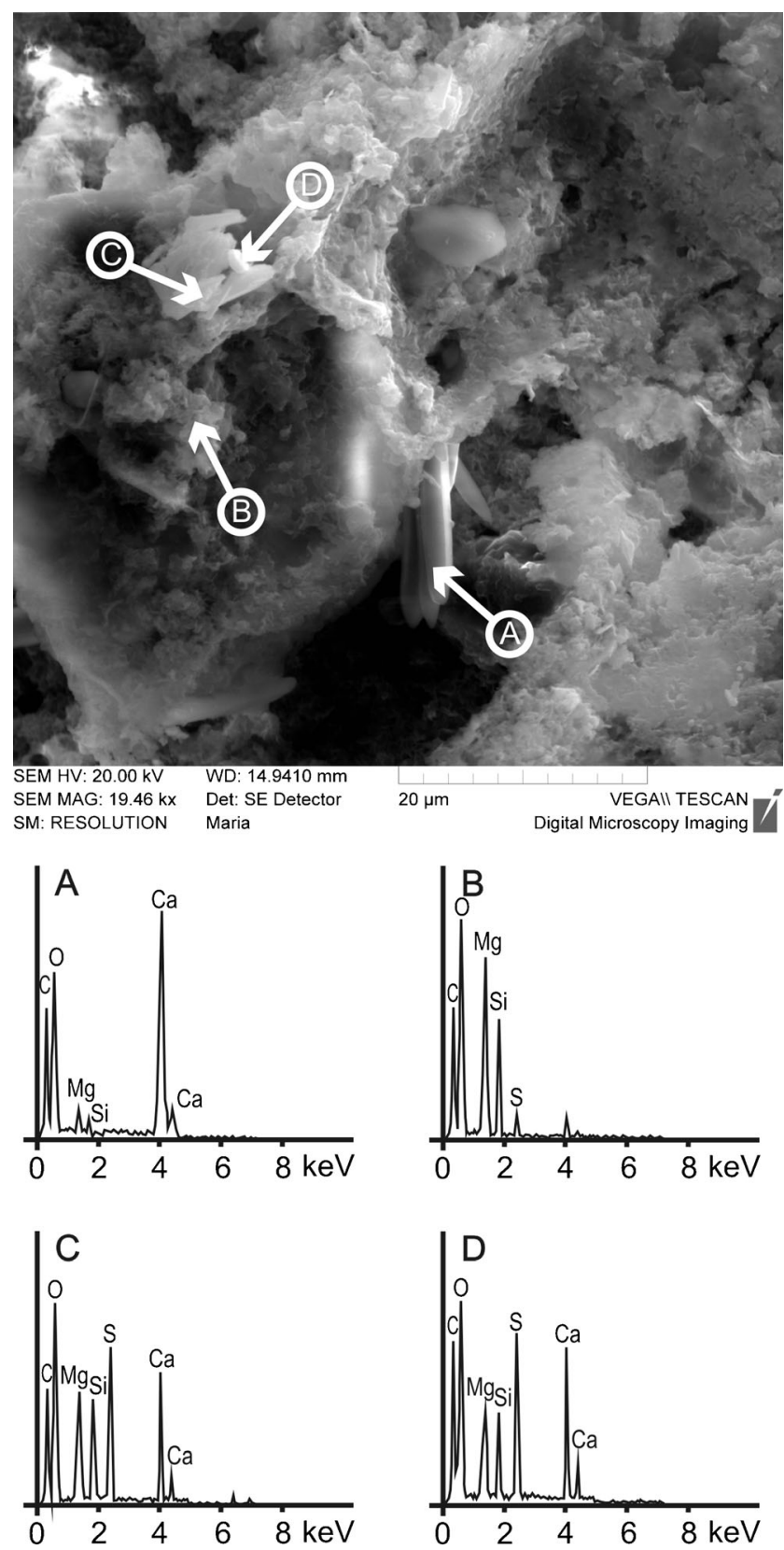

Fig. 7 Secondary electron images and EDS spectra of Baroque Mortar (finishing layer)

carbonate phase (magnesite) in exterior areas. The striking feature concerning hydromagnesite from studied mortars is that we have detected only hydromagnesite in both external and internal layers of mature (Baroque) plastering mortars, with no signs of magnesite and brucite.

Quartz (Figs. 8 and 9), feldspars, and mica (Fig. 9) definitely correspond to the sandy aggregates of the studied mortars. Their presence indicates that very fine grains of aggregate have passed through a $63-\mu \mathrm{m}$-size sieve, which is frequently reported in the literature (Biscontin et al. 2002; Maravelaki-Kalaitzaki et al. 2003; Labiadh et al. 2009; Bartz et al. 2012). 


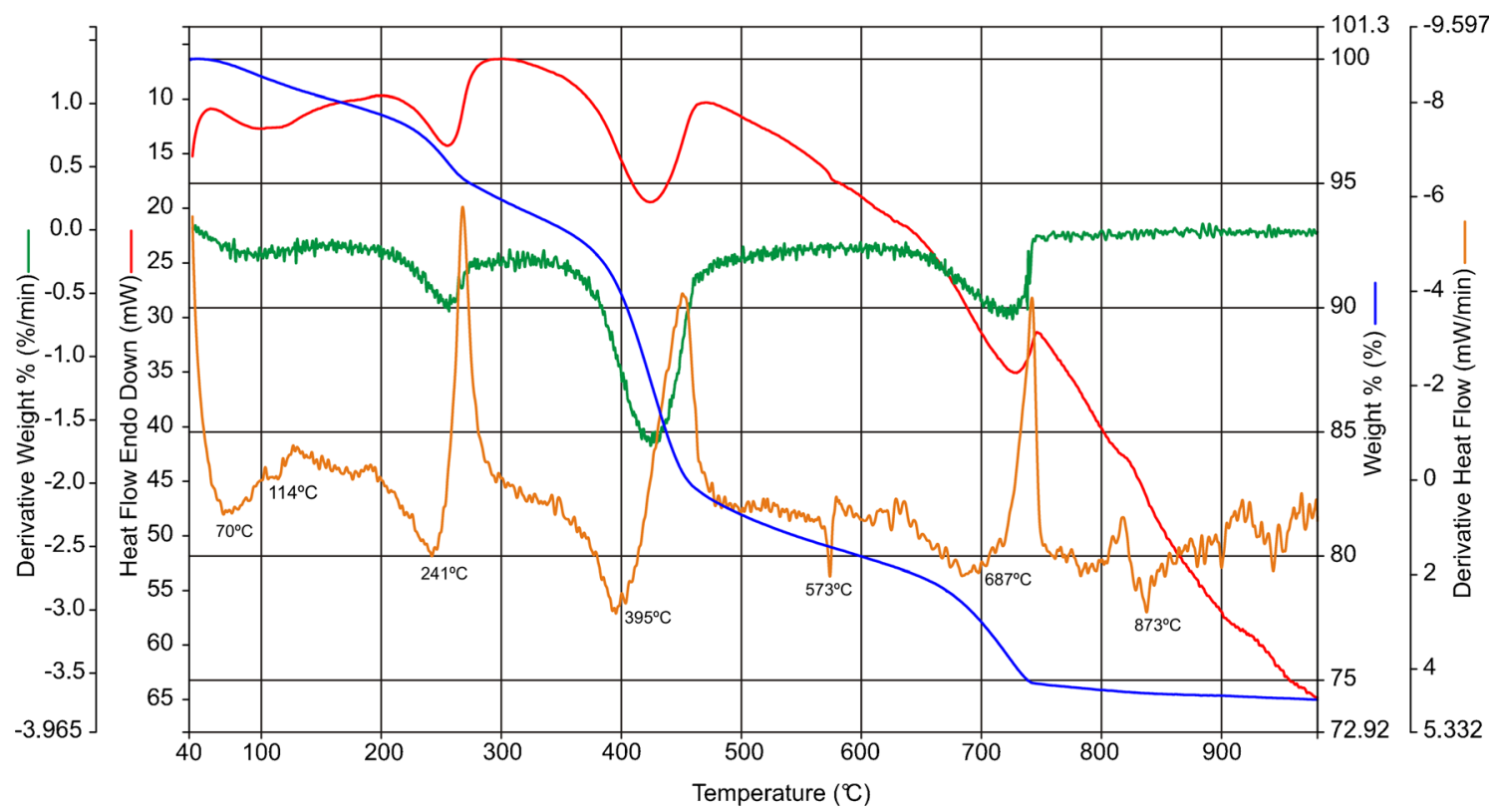

Fig. 8 DSC/TG plot of the binder fraction $(<63 \mu \mathrm{m})$ separated from the Baroque mortar

Fig. 9 X-ray diffraction patterns of Gothic and Baroque mortar

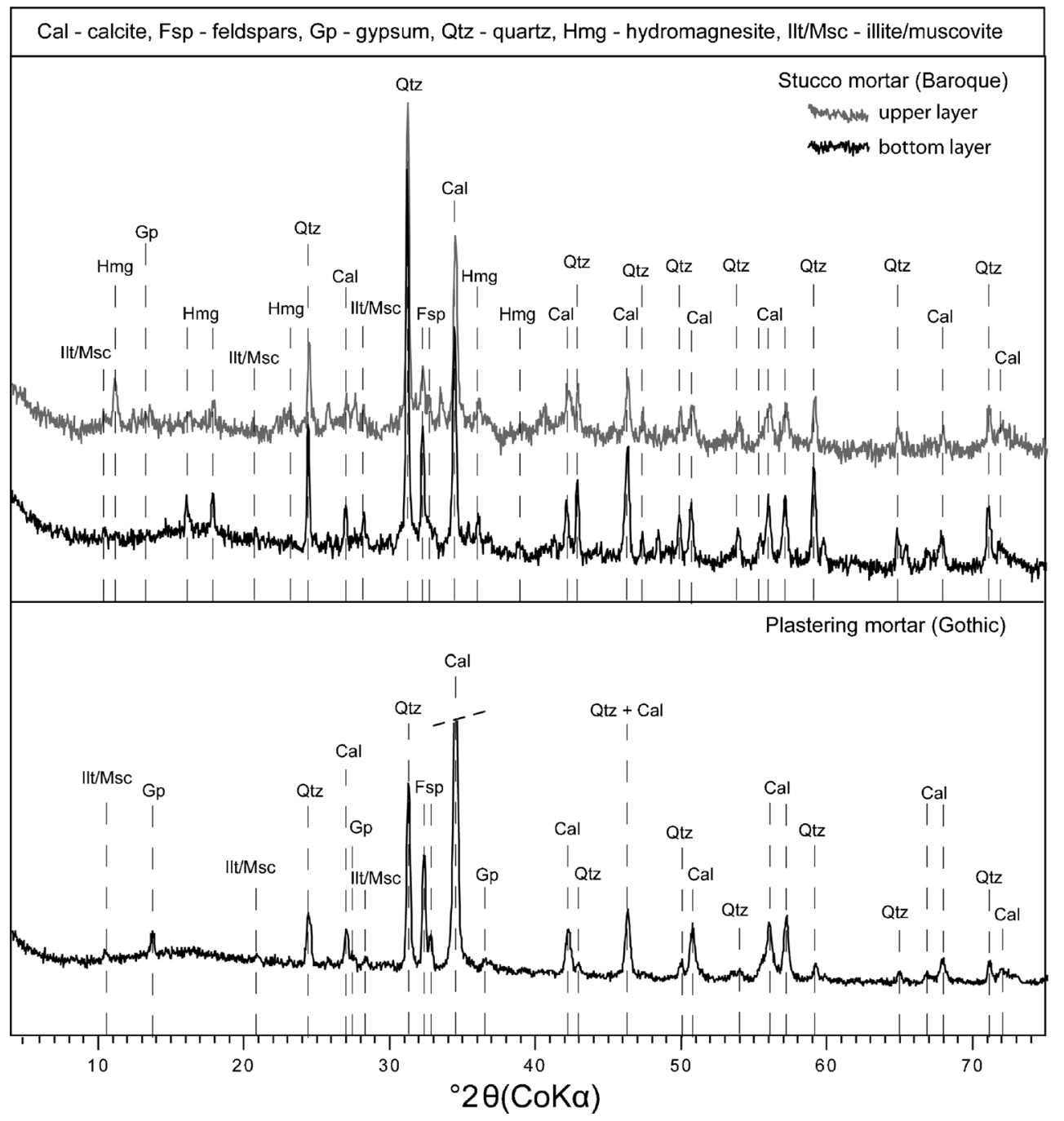


The binder is extensively weathered and cracked as a result of a secondary gypsum crystallization (Fig. 5a, b). This secondary phase, occurring as fine prismatic crystals, fills cracks and forms thin encrustations on the filler's grains. In the case of two-layered mortars, both of them are weathered. The gypsum presence is confirmed by XRD analysis (Fig. 9) and by DSC-TG analysis, recording relatively small weight loss, accompanied with shallow single endotherm at approximately $120^{\circ} \mathrm{C}$ (Fig. 8). Since the temperature of dehydration of gypsum depends on many factors, such as sample weight, heating rate, etc. (Ramachandran et al. 2002), we observe only onestep endothermal reaction instead of typical two-step evolution of water. The occurrence of gypsum in all mortars (singlelayer as well as two-layered) confirmed the observations of Diekamp et al. (2012) and Siedel et al. (2010) that magnesium mortars, similarly to calcitic ones, are strongly susceptible to weathering and formation of secondary salts (gypsum). On the other hand, no signs of other secondary phases, i.e., Mg sulfates (hexahydrite, epsomite), reported by Diekamp et al. (2012), have been found in studied mortars which may be explained by a higher solubility of these salts comparing to gypsum.

The occurrence of hydromagnesite in mortars is strictly related to carbonation of a dolomitic lime. It is produced from a carbonatic rock (dolostone) or metamorphic rock (marble), containing a mixture of calcium and magnesium carbonates, typically calcite and dolomite. Since these rocks are relatively rare in the area of Kamieniec Zabkowicki, we conclude that it is easy to find the deposits of rocks used for lime burning. Thus, we made a detailed study of geological background in the perimeter of approximately $50 \mathrm{~km}$ from the ABVM\&JE church. As a result, we have found that there are only two occurrences of Mg-rich rocks. The first one is the Wapienna Hill, located $8.5 \mathrm{~km}$ north of the ABVM\&JE church, in the vicinity of Stolec town. The second one is located $11.5 \mathrm{~km}$ south of the ABVM\&JE church in the Złoty Jar near the vicinity of Złoty Stok. The carbonatic rocks in the Stolec vicinity form up to 4.5 -m-thick layers between mica or quartzofeldspathic schists (Andrzejewski 2000). They occur in many varieties, starting from typical calcitic marbles, ending with calcite-dolomite marble containing up to $65 \%$ vol. of dolomite. Therefore, it is possible that the lime could be produced in Stolec, particularly that Madziarz and Sztuk (2005) mentioned the existence of limekiln situated close to the mining pit. However, it is more likely that source of the lime for production of studied mortars is represented by Mg-rich rocks from the Złoty Stok area. Several arguments seem to support the second hypothesis. Firstly, large tracts of forest, located westward of the Złoty Stok, were owned by Cistercians from the Kamieniec Zabkowicki (Wyrwa et al. 1999). This area is known from intensive gold mining, which, according to Łuszczkiewicz and Muszer (1997), started already in the tenth century. On the other hand, the first documented mention of mining works points to 1273 (Krzyżanowski et al. 2013) when the King Henry IV Probus gave the privilege of exploitation of minerals to Cistercians from the Kamieniec monastery. Besides, the gold-bearing gneisses, mica schists, and amphibolites, in the Złoty Stok area small bodies of dolomitic marbles, containing at least $66.6 \%$ of dolomite also occur (Kowalski 1967). These rocks were exploited for the purposes of lime burning, and numerous remnants of limekilns are preserved until today. This activity started in the sixteenth century, over a century earlier than rebuilding and baroquization of the ABVM\&JE church. Finally, we do not exclude, as it was suggested by Bartz et al. (2013), the possible provenance of the rocks used for lime burning from the vicinity of Ołdrzychowice. However, it is twice as far away as Złoty Stok. Additionally, the transportation of raw material (dolomitic marble/lime) requires to overcome the mountain range. Thus, such localization is less plausible. Summarizing, it is most probable that lime for rebuilding of the ABVM\&JE church in Baroque times was produced and transported from the Złoty Stok area.

Gothic mortars, belonging to the second group, are singlelayered and consist of filler generally similar in composition and morphology to the filler from the Baroque ones. However, large grains $(1.0-2.0 \mathrm{~mm}$, mainly crystalline rocks with subordinate mica schists) are more common, better rounded (Fig. 5), and the filler contains accessory glauconite and sparse charcoal and brick particles. This suggests that the filler is of the same origin, as the filler in Baroque mortars; however, it contains important admixture of glacial terrigenous sediments of Quaternary age. We assume that, as it is suggested by Elsen (2006), the charcoal is a remnant of fuel, used during calcinations of a lime. In contrast to Baroque mortars, the brick particles are accidental component. It could be derived from the internal parts of a limekiln. The binder seen in polarized light looks similar to Baroque one, is rich in lime lumps, and is weathered, but to a smaller extent (Fig. 5). XRD patterns (Fig. 9), SEM-EDS data (Fig. 11), and thermograms (Fig. 10) show that calcite is a main component of the binder. It derives from the carbonation of a slaked lime, quartz, and illite/muscovite originating from the aggregate that passed sieve $63 \mu \mathrm{m}$. The small intensity of gypsum peaks (Fig. 9) and weak endothermal reaction at approximately $130{ }^{\circ} \mathrm{C}$ (Fig. 10) denote a small degree of binder weathering. The thermogram shows slight deflection of DTG at the temperature range of $400-500{ }^{\circ} \mathrm{C}$ (Fig. 10). In this temperature range, portlandite dehydrates (Adams et al. 1998; Moropoulou et al. 2005), which means that complete carbonation has not been reached yet. Moropoulou et al. (2005) point out that the process of carbonation of mortars, especially those of large thickness, is slow and can leave unaltered portlandite. Since the XRD patterns do not exhibit the presence of portlandite, we assume that it exists but in small amount and/or is weakly crystallized. This stays in good agreement with simple 
alkalinity test, performed by means of phenolphthalein (Lawrence 2005) which gave negative result.

According to the collected data, we have attempted to assess the provenance of the raw materials, used for lime burning. Since the binder of Gothic mortars is composed of almost pure micrite, the lime had to be produced from calcitic limestone or calcitic marble. In the Lower Silesia, there are many outcrops of carbonate rocks and related lime-burning remnants (Lorenc and Mazurek 2010). However, we assumed that transportation of raw material for long distances was not realistic in the thirteenth and fourteenth centuries. For example, intensive exploitation of carbonate rocks and production of lime took place in Strzelin region. Remnants of the former lime production are represented by limekilns situated in Gębczyce, Przeworno, and Nowina (Tarka 2012). These places are located not too far (approximately $25-30 \mathrm{~km}$ ) from the Kamieniec, but pure marble occurs in Przeworno only (Wojnar 1995). The other two occurrences are occupied by calc-silicate rocks, rich in pyroxene, and whose relics were not find in Gothic mortars. Moreover, the production and transportation of lime to the Kamieniec are supported by the fact that in the fourteenth century, there was an operating limekiln in Przeworno (Lorenc and Mazurek 2010). In addition, the "grainy" inner structure of some lime lumps (i.e., nonfully calcined limestone lumps) resembles much the structure of medium-grained marble from Przeworno.

So far, little is known about the lime calcination in the Lower Silesia (SW Poland; Lasota and Piekalski 1988). Archaeological studies, conducted in the Ołbin area (nowadays, a district of Wrocław city), showed that there were two lime kilns, operating in twelfth century, producing lime for the needs of Benedictine Abbey (op. cit.). Limestone composed
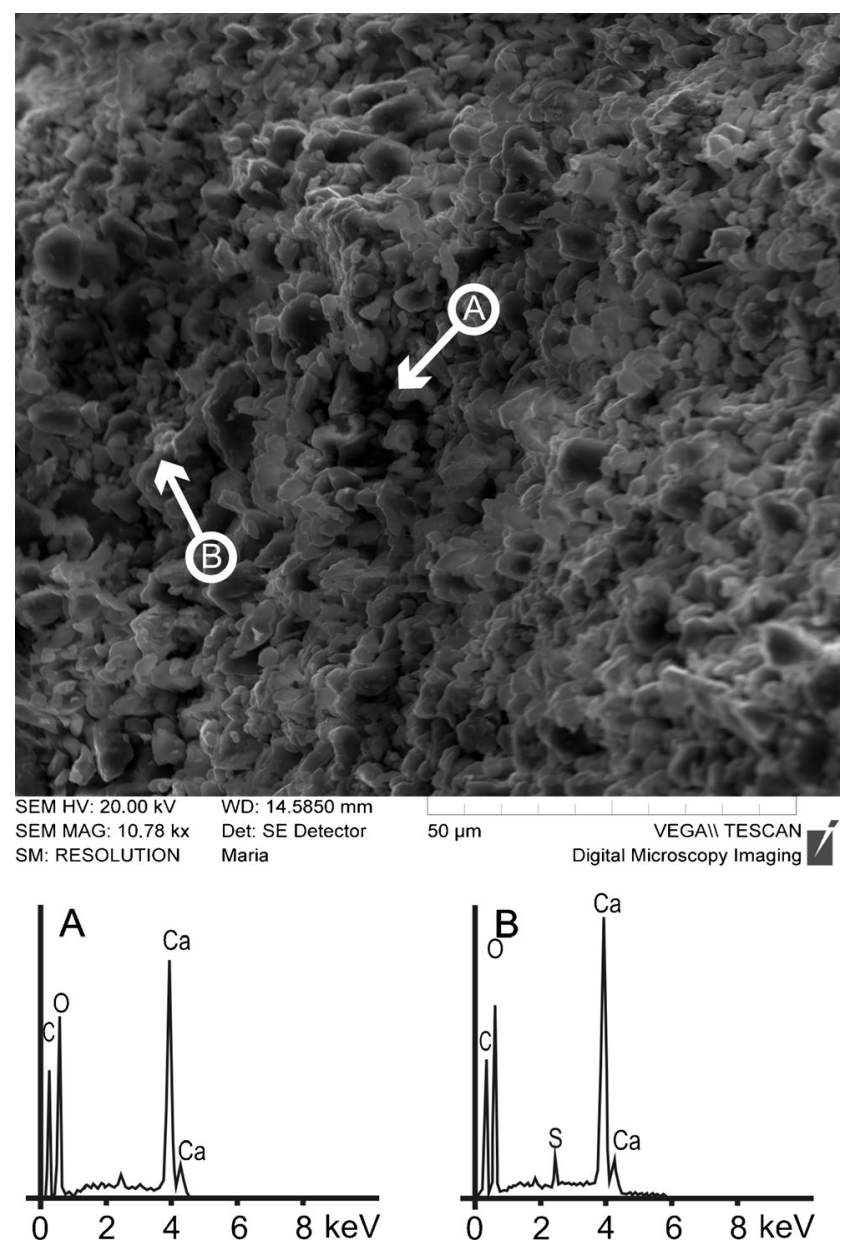

Fig. 11 Secondary electron images and EDS spectra of Gothic Mortar

of calcite, transported from the Opole region over a distance of about $80-90 \mathrm{~km}$, was used as a batch material for these kilns.

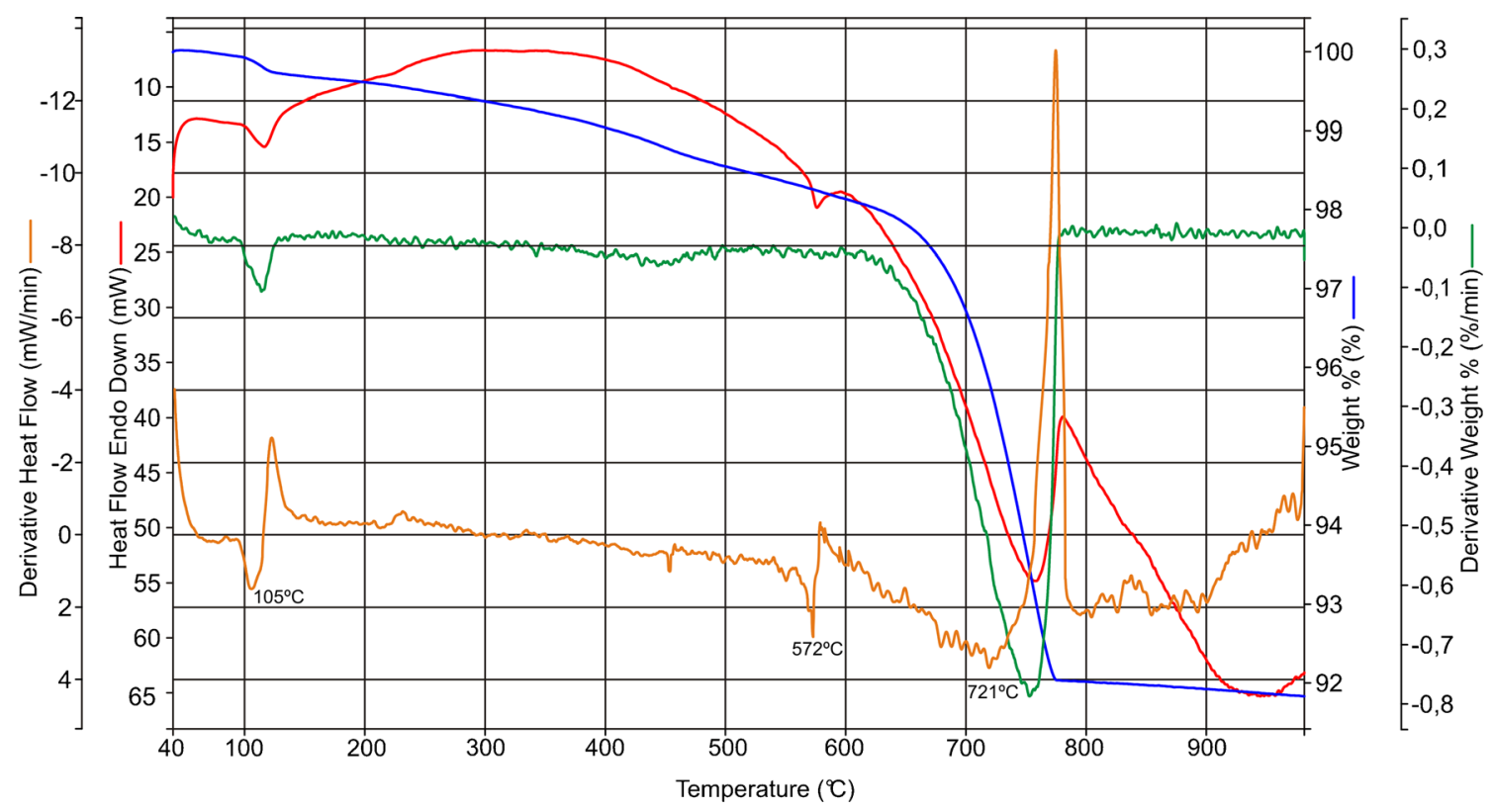

Fig. $10 \mathrm{DSC} / \mathrm{TG}$ plot of the binder fraction $(<63 \mu \mathrm{m})$ separated from the Gothic mortar 
It is three times as far away as in our case. This documents, that contrary to the Kamieniec Zabkowicki case, the raw materials for lime burning were occasionally transported over a long distance in twelfth to thirteenth century in Lower Silesia. The common lime, consisting of pure calcium hydroxide, was applied for erecting lower Silesian Early Medieval castles in Wrocław, Ostrów Tumski (Bartz et al. 2014), and Wleń (Giergiczny and Michniewicz 1995). Totally different technology was used for construction of Cistercian church in Łękno (Central Poland). Its foundations were made with use of mixture composed mainly of clay minerals with admixture of calcite and gypsum (Skibiński et al. 1995). A certain convergence in use of dolomitic lime is observed, comparing Baroque construction phases in post-Cistercian abbeys in Lower Silesia. This kind of mortar was used during baroquization in Cistercian church in Lubiąż, located c.a. $90 \mathrm{~km}$ to the northwest from Kamieniec Ząbkowicki (Bartz et al. 2013). It indicates that a certain unification of lime technology existed in Cistercian masonry works, during the Baroque era.

\section{Conclusions}

Mineralogical studies allowed us to precisely determine the provenance - not only for stones, but also for the raw material used for lime burning, subsequently applied in jointing and plastering mortars of two main constructing phases. The Baroque (dolomitic) mortars have binder calcined from carbonate rocks rich in magnesium. This rock variety is relatively uncommon in the area close to the Cistercian church. Hence, particularly, this peculiarity allowed us to narrow down the possible deposits and indicate dolomitic marble from the Złoty Stok area as the most likely source. Additionally, our petrographic data stays in good agreement with results of archaeological research, suggesting the use of local mica schist as far back as in medieval times. The primary building material-fine-grained mica schist - was mined very close to the building site. Some part of the building stone could even come from foundation trench. The coarse-grained mica schist, which is less common, was mined and transported for longer distance, at least $1.5 \mathrm{~km}$ far from the church. In the case of less common sandstone, acquired data point to distant Radków, as a provenance for this type of rock. Thus, it indicates that Radków sandstone was transported for relatively long distance (tens of kilometers) in Medieval times (Fig. 3b). The Gothic mortars, as well as Baroque ones, were prepared on the basis of local petrographically immature and poorly sorted eluvium. Numerous fragments of mica schist are the main components, accompanied with subordinate glacial terrigenous material. We did not observe the presence of mature (i.e., well rounded and well sorted) sediment, which could suggest an admixture of fluvial sediment, derived from the adjacent river Nysa Kłodzka. Both types of mortars (i.e., magnesium one and calcitic one) were subjected to intense weathering, resulting in numerous cracks filled with secondary gypsum. However, we did not observe other magnesium secondary salts in dolomitic mortars, like hexahydrite and/or epsomite, which were successively washed out by rainwaters.

Acknowledgments The research was supported by the University of Wroclaw, Grant 1017/S/ING/12, and National Science Centre Project, Grant UMO-2012/07/B/ST10/03820.

Open Access This article is distributed under the terms of the Creative Commons Attribution 4.0 International License (http:// creativecommons.org/licenses/by/4.0/), which permits unrestricted use, distribution, and reproduction in any medium, provided you give appropriate credit to the original author(s) and the source, provide a link to the Creative Commons license, and indicate if changes were made.

\section{References}

Adams J, Dollimore D, Griffiths DL (1998) Thermal analytical investigation of unaltered $\mathrm{Ca}(\mathrm{OH})_{2}$ in dated mortars and plasters. Thermochim Acta 324:67-76

Agostino R, Barone G, Mazzoleni P, Raneri S, Sabatino G, Sica MM (2013) Mortars and plasters from the Bruttii-Roman city of Taureana (Palmi, RC, Italy) - preliminary data. Per Mineral 82:489-501

Alvarez I, Navarro I, Martín A, García Casado PJ (2000) A study of the ancient mortars in the north tower of Pamplona's San Cernin church. Cem Concr Res 30:1413-1419

Andrzejewski W (2000) Lithology and petrogenesis of carbonate rocks from the neighbourhood of Stolec village (Niemcza-Kamieniec Zone-SW Poland). Prz Geol 48:182-186

Arioglu N, Acun S (2006) A research about a method for restoration of traditional lime mortars and plasters: a staging system approach. Build Environ 41:1223-1230

Bartz W, Rogóż J, Rogal R, Cupa A, Szroeder P (2012) Characterization of historical lime plasters by combined non-destructive and destructive tests: the case of the sgraffito in Bożnów (SW Poland). Constr Build Mater 30:439-446

Bartz W, Kierczak J, Gąsior M (2013) Mineralogical characterization of Baroque magnesian mortars from the Cistercian church in Kamieniec Ząbkowicki (SW Poland). Mineral-Spec Pap 41:31

Bartz W, Chorowska M, Gąsior M, Kościuk J (2014) Petrographic study of Early Medieval mortars from the castle in Ostrów Tumski (Wrocław, SW Poland). 4th Central European Mineralogical Conference (CEMC) Skalský Dvůr, Czech Republic

Biscontin G, Pellizon Birelli M, Zendri E (2002) Characterization of binders employed in the manufacture of Venetian historical mortars. J Cult Herit 3:31-37

Blaeuer C, Kueng A (2007) Examples of microscopic analysis of historic mortars by means of polarizing light microscopy of dispersion and thin sections. Mater Charact 58:1199-1207

Bruni S, Cariati F, Fermo P, Pozzi A, Toniolo L (1998) Characterization of ancient magnesian mortars coming from northern Italy. Thermochim Acta 321:161-165

Carò F, Riccardi MP, Mazzilli Savini MT (2008) Characterization of plasters and mortars as a tool in archaeological studies: the case of Lardirago castle in Pavia Northern Italy. Archaeometry 50(1):85100

Crisci GM, Franzini M, Lezzerini M, Mannoni T, Riccardi MP (2004) Ancient mortars and their binder. Per Mineral 73:259-268 
Dheilly RM, Bouguerra A, Beaudoin B, Tudo J, Queneudec M (1999) Hydromagnesite development in magnesian lime mortars. Mater Sci Eng A 268:127-131

Diekamp A, Konzett J, Tartarotti P, Mirwald PW (2012) Dolomitic lime mortar and the impact of $\mathrm{SO}_{2}$-pollution. 12th International Congress on the Deterioration and Conservation of Stone. Columbia University, New York, pp 1-9

Ehling A (1999) Die oberkretazischen Bausandsteine Schlesiens. Dissertation, Universität Hannover

Elsen J (2006) Microscopy of historic mortars - a review. Cem Concr Res 36:1416-1424

Elsen J, Mertens G, van Balen K (2011) Raw materials used in ancient mortars from the Cathedral of Notre-Dame in Tournai (Belgium). Eur J Mineral 23:871-882

Formia A, Serra CL, Zerbinatti M, Tulliani J-M (2014) The plasters of the Sacro Monte of Varallo Sesia. From the characterisation to the proposition of a restorative mix. Case Stud Constr Mater 1:46-52

Franzini M, Leoni L, Lezzerini M, Sartori F (1999) On the binder of some ancient mortars. Mineral Petrol 67:59-69

Giergiczny Z, Michniewicz J (1995) Wyniki badań składu fazowego zapraw budowlanych pochodzacych z zamku we Wleniu. Ślaskie Sprawozdania Archeologiczne 36:255-265

Gunia T (1979) Nowe stanowiska mikroflory w metamorfiku wschodnich okolic Niemczy. In: T. Gunia (ed.), Materiały konferencji terenowej: Wybrane zagadnienia stratygrafii, petrografii i tektoniki wschodniego obrzeżenia gnejsów sowiogórskich i metamorfiku kłodzkiego, Nowa Ruda, pp 63-78

Gurgurewicz J, Bartz W (2011) Deformational history of metavolcanic rocks from the Kamieniec Zabkowicki Metamorphic Belt (ForeSudetic Block, SW-Poland): quartz [c]-axis preferred orientation study. Acta Geol Pol 61(3):289-305

Józefiak D (2000) Geothermobarometry in staurolite-grade mica schists from the southern part of the Niemcza-Kamieniec Metamorphic Complex (Fore-Sudetic Block, SW Poland). N Jb Mineral Abh 175(3):223-248

Kowalski WM (1967) Metamorphic rocks from Zloty Stok (Lower Silesia). Pr Geol Kom Nauk Geol PAN Oddz w Krakowie 42:7-77

Kozlowski R, Wittenburg C, Zeunert A (2014) Stucco marble in the Dukes Chapel in Krzeszów, Poland - microclimate and degradation mechanisms. Restor Build Monuments 6(4):463-480

Krzyżanowski K, Wójcik D, Furmankiewicz M (2013) Emanuel adit in Złoty Stok. In: Zagożdżon PP, Madziarz M (eds) Dzieje górnictwaelement europejskiego dziedzictwa kultury, 5. Oficyna Wydawnicza Politechniki Wrocławskiej, Wrocław, pp 139-160

Labiadh MR, Ouezdou MB, Hajjem BT, Mensi R (2009) Characterization of waterproof-covering mortars on Ottoman monuments of "Ghar El Melh" (Tunisia). Constr Build Mater 23:423-433

Labus M (2011) Parametry przestrzeni porowej jako determinanty podatności na wietrzenie surowców skalnych dolnośląskich piaskowców ciosowych. Wydawnictwo Politechniki Śląskiej, Gliwice

Labus M, Hetmaniok J (2004) The categorisation of devastation caused by the erosion of construction material upon the example of Swina Castle in lower Silesia. Ochrona Zabytkow 3(4):215-223

Lasota C, Piekalski J (1988) Produkcja wapna na placu budowy romańskiego opactwa benedyktynów na Ołbinie we Wrocławiu. Kwartalnik Historii Kultury Materialnej, T. 36, Z. 1:29-41

Lawrence RMH (2005) A critical review of techniques used to assess carbonation in lime mortars. International Building Lime Symposium, Orlando, pp 1-15

Lisowska E (2013) Production and distribution of stone raw materials in the Early Middle Ages in Lower Silesia. Uniwersytet Wrocławski Instytut Archeologii, Wrocław

Lorenc MW, Mazurek S (2010) Selected, new proposals of geotouristic attractions from Lower Silesia. Geoturystyka 3-4:3-18
Łuszczkiewicz A, Muszer A (1997) Gold in mine wastes from Złoty Stok region (SW Poland). Physicochem Probl Miner Process 31:197-209

Madziarz M, Sztuk H (2005) Exploration of old mining positions at Lower Silesia region. Prace Naukowe Instytutu Górnictwa Politechniki Wrocławskiej Konferencje 111(43):163-172

Maravelaki-Kalaitzaki P, Bakolas A, Moropoulou A (2003) Physiochemical study of Cretan ancient mortars. Cem Concr Res 33: 651-661

Mazur S, Józefiak D (1999) Structural record of Variscan thrusting and subsequent extensional collapse in the mica schists from vicinities of Kamieniec Ząbkowicki, Sudetic foreland, SW Poland. Ann Soc Geol Pol 69:1-26

Michalska D, Pazdur A, Czernik J, Szczepaniak M, Żurakowska M (2013) Cretaceous aggregate and reservoir effect in dating of binding materials. Geochronometria 40:33-41

Middendorf B, Baronio G, Callebaut K, Hughes J (2000) Chemicalmineralogical and physical-mechanical investigations of old mortars. Proceedings of the International RILEM-workshop "Historic mortars: characteristics and tests", Paisley

Montoya C, Lanas J, Arandigoyen M, Navarro I, Garcia Casado PJ, Alvarez JI (2003) Study of ancient dolomitic mortars of the church of Santa Maria de Zamarce in Navarra (Spain): comparison with simulated standards. Thermochim Acta 398:107-122

Montoya C, Lanas J, Arandigoyen M, García Casado PJ, Alvarez JI (2004) Mineralogical, chemical and thermal characterisations of ancient mortars of the church of Santa María de Irache monastery (Navarra, Spain). Mater Struct 37(6):433-439

Moropoulou A, Bakolas A, Anagnostopoulou S (2005) Composite materials in ancient structures. Cem Concr Compos 27:295-300

Origlia F, Gliozzo E, Meccheri M, Spangenberg JE, Turbanti Memmi I, Papi E (2011) Mineralogical, petrographic and geochemical characterisation of white and coloured Iberian marbles in the context of the provenancing of some artefacts from Thamusida (Kenitra, Morocco). Eur J Mineral 23:857-869

Paama L, Pitkänen I, Rönkkomäki H, Perämäki P (1998) Thermal and infrared spectroscopic characterization of historical mortars. Thermochim Acta 320:127-133

Pettijohn FJ, Potter PE, Siever R (1987) Sand and sandstone. 2nd ed. Springer-Verlag

Ramachandran VS, Paroli RM, Beaudoin J, Delgado A (2002) Handbook of thermal analysis of construction materials. Noyes Publications William Andrew Publishing, Norwich

Sandrolini F, Franzoni E (2010) Characterization procedure for ancient mortars' restoration: the plasters of the Cavallerizza courtyard in the Ducal Palace in Mantua (Italy). Mater Charact 61:97-104

Siedel H, Michalski S, Ullrich B (2010) Characterisation of dolomitic lime mortars from the Benedictine Monastery in Riesa, Saxony (Germany). In: Válek J, Groot C, Hughes JJ (eds) 2nd Historic Mortars Conference and RILEM TC 203-RHM Final Workshop. RILEM Publications s.a.r.1, Bagneux, pp 365-372

Skibiński S, Kęsy-Lewandowska M, Domagalski W (1995) Wyniki badań składu fazowego zapraw budowlanych pochodzących z reliktów architektonicznych rotundy oraz pierwszej fazy budowy kościoła cysterskiego w Łeknie. In A. M. Wyrwa (ed.) Studia i Materiały do Dziejów Pałuk, T. 1, Poznań, pp. 195-214

Tarka R (2012) Koncepcja utworzenia geoparku na obszarze Wzgórz Niemczańsko-Strzelińskich. In: Tarka R, Moskwa K (eds) Walory przyrody nieożywionej Wzgórz Niemczańsko-Strzelińskich. Uniwersytet Wrocławski, Wrocław, pp 37-47

Wojnar B (1995) Structural analysis and petrology of metamorphic rocks of the southern part of the Strzelin massif. Prace geologicznomineralogiczne XLVI:3-74

Wyrwa AM, Strzelczyk J, Kaczmarek K (1999) Monasticon cisterciense poloniae. T 1, 2, Wydawnictwo Poznańskie, Poznań 